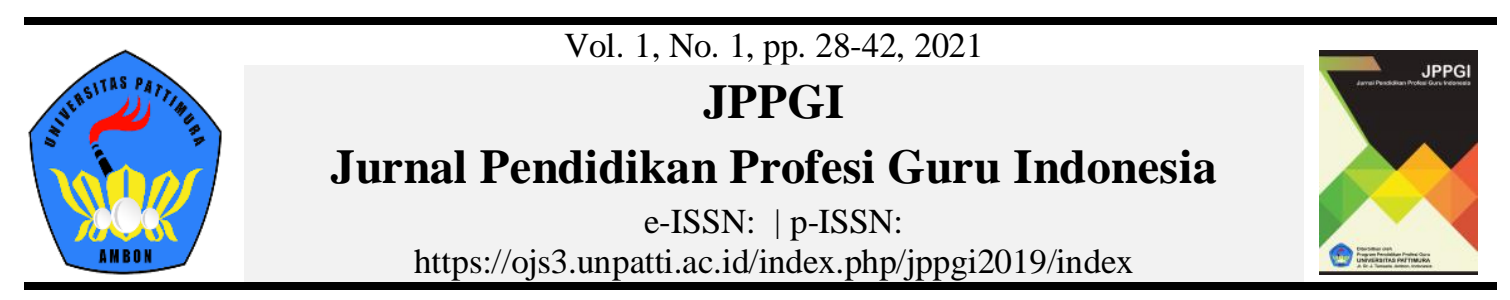

\title{
Manajemen Pembelajaran
}

\author{
Mathias Gemnafle $^{1^{*}}$, John Rafafy Batlolona ${ }^{2}$ \\ ${ }^{1}$ Sekolah Tinggi Filsafat Teologi, GKI Izaak Samuel Kijne, Jayapura, Indonesia \\ ${ }^{2}$ Program Pendidikan Profesi Guru Fakultas Keguruan dan Ilmu Pendidikan, Universitas Pattimura- \\ Ambon, Indonesia \\ *Corresponding e-mail: johanbatlolona@gmail.com
}

Received: 20 August $2020 \quad$ Accepted: 01 December $2020 \quad$ Online Published: 08 February 2021

\begin{abstract}
Abstrak: Tulisan ini disusun dengan maksud mengeksplorasi masalah manajemen pembelajaran di sekolah yang patut mendapat perhatian semua pihak. Masalah mutu lulusan diberbagai jenjang dan jenis sekolah dipengaruhi pula oleh kualitas manajemen pembelajaran yang diterapkan di sekolah. Fakta bahwa seluruh proses dan hasil belajar yang dicapai siswa sangat tergantung kepada peranan, tugas dan tanggung jawab kepala sekolah dan guru di sekolah. Salah satu tugas dan peran kepala sekolah dan guru adalah pengelola proses pembelajar yang bertumpu pada kinerja yang bermutu. Proses pengelolaan di sekolah harus dimulai dari tahap perencanaan, pengorganisasian, pelaksanaan, pengawasan, penilaian dan tindak lanjut. Yang menjadi tuntutan itu adalah supaya proses manajemen pembelajaran dimaksud dilakukan dengan baik dan benar oleh guru yang profesional, sehingga memuat konten pembelajaran yang mampu menghasilkan kompetensi akademik dan non akademik yang utuh di dalam diri siswa. Oleh karena itu, kualitas kerja guru dalam merencanakan sampai mengevaluasi dan menggunakan hasil belajar peserta didik, berkorelasi positif dengan mutu lulusan di sekolah. Guru yang memiliki kinerja manajerial positif yang tercermin secara efektif dalam proses belajar mengajar, tentu akan memberikan dampak besar terhadap hasil pembelajaran yang dicapai oleh peserta didiknya. Pelaksanaan proses belajar mengajar di sekolah didahului dengan pekerjaan manajemen yang baik dan benar, adalah keniscayaan kerja setiap pemimpin pembelajaran yang disebut Kepala Sekolah dan guru selaku eksekutor pembelajaran di sekolah.
\end{abstract}

Kata kunci: Manajemen, Pembelajaran, Hasil belajar

To cite this article:

Gemnafle, M., Batlolona, J. R. (2021). Manajemen pembelajaran. JPPGI: Jurnal Pendidikan Profesi Guru Indonesia, 1(1), 28-42.

\section{PENDAHULUAN}

Implementasi pembelajaran dalam proses pembelajaran di sekolah yang ditata secara formal - struktural untuk mencapai tujuan pendidikan, didalamnya melibatkan komponen manusia, sarana prasarana, fasilitas, suasana, ruang, waktu, dana, dan berbagai regulasi. Tugas kepala sekolah adalah memimpin, mengarahkan dan mengendalikan seluruh aktivitas di sekolah. Sedangkan tugas guru adalah mendidik, melakukan pembelajaran dan menilai hasil belajar siswa. Selain itu, tugas siswa untuk aktif belajar. Tenaga kependidikan mendorong seluruh proses pembelajaran, mengelolah sejumlah dana secara benar dan bertanggng jawab. Komponen lain yaitu 
orang tua dan masyarakat yang memiliki kekuatan potensial untuk mendukung seluruh program sekolah, pengendalian dan kontrol dari pihak penyelenggara pendidikan, mulai dari pusat, provinsi hingga pada kabupaten dan kota. Semua komponen dan unsur pendukung pembelajaran tersebut harus dikelolah secara baik dan efektif agar hasil pembelajaran yang diraih oleh setiap sekolah benar-benar berada pada tingkat maksimal, baik pada aspek akademik maupun non akademik.

Jika ditinjau dari perspektif manajemen pendidikan, maka semua komponen yang disebutkan di atas dinamakan sumberdaya pendidikan. Dalam mencapai hasil belajar yang maksimal yang merupakan sasaran akhir dari program pendidikan di sekolah, maka semua sumber daya pendidikan tersebut patutlah dikelola secara efektif dan efisien. Pengelolaan semua sumber daya pendidikan dimaksud secara efektif dan efisien sehingga memberikan efek yang bernilai tinggi bagi pencapaian tujuan pendidikan, pembelajaran, dan pemimpin pendidikan yang luar biasa. Pada abad saat ini tidak diperlukan pemimpin pendidikan dengan kemampuan biasa, melainkan yang luar biasa (Khoshhal \& Guraya, 2016). Diharapkan di masa yang akan datang dapat melakukan reformasi pemberdayaan semua sumber daya pendidikan, khususnya ditingkat satuan pendidikan, agar benar-benar mampu memenuhi tuntutan publik (Richter \& McPherson, 2012). Saat ini makin kuat tuntutan pada sekolah atau perguruan tinggi untuk mencapai prestasi pada tingkat yang lebih tinggi. Lembaga sekolah dan perguruan tinggi makin diharapkan mampu melakukan reformasi dalam meningkatkan kinerja yang berbasis pada institusi.

Pemikiran yang dikemukakan mencerminkan adanya harapan besar masyarakat Indonesia kepada sektor pendidikan formal, mulai dari pendidikan dasar hingga perguruan tinggi yang harus dikelola dengan baik. Pemimpin pendidikan yang cerdas dan profesional, dapat mengelola semua sumber daya pendidikan pada setiap satuan pendidikan itu secara efektif dan efisien, termasuk mengelola proses pembelajaran secara bertanggung jawab, sehingga menghasilkan lulusan yang bermutu tinggi dan mampu membangun bangsa serta mampu bersaing secara global (Alvunger, 2015).

Kenyataan beberapa waktu yang lalu hingga saat ini, nampaknya belum terwujud. Beberapa hasil analisis femenologis-empiris serta kajian lapangan sebagai realita antara lain. 1) Lulusan dari bebagai sekolah atau perguruan tinggi belum siap memasuki dunia kerja karena minimnya kompetensi yang dimiliki (O'Leary, 2017). 2) bekal kecakapan yang diperoleh dari lembaga pendidikan tidak memadai untuk dipergunakan secara mandiri karena yang dipelajari di sekolah dan perguruan tinggi sering kali hanya teori sehingga peserta kurang memiliki keterampilan inovatif dan kreatif (Marshall, 2017). 3) Hasil survey UNESCO pada tahun 2012, yang menyatakan bahwa Indonesia berada di peringkat ke 64 dari 120 negara, berdasarkan penilaian terhadap Indeks Pembangunan Pendidikan (UNESCO, 2012).

Masalah mutu pendidikan di Indonesia belum membaik, walaupun telah dilakukan berbagai upaya untuk memperbaikinya. Misalnya perumusan dan penetapan berbagai regulasi yang mengatur pendidikan, revisi kurikulum pendidikan dasar dan menengah yang dilakukan secara periodik, desentralisasi pengelolaan pendidikan, peningkatan kualitas akademik dan profesionalisme guru dan dosen, perbaikan kesejahteraan guru dan dosen, perbaikan dan peningkatan sarana prasarana pendidikan di semua satuan pendidikan, perbaikan manajemen pembelajaran pada semua satuan pendidikan, pengembangan pembelajaran yang berbasis pada standar mutu pengelolaan, mulai dari pendidikan dasar sampai pada pendidikan tinggi. Oleh karena itu, bagaimana 
implementasi manajemen pembelajaran secara baik dilihat, maka lewat kajian ini di jelaskan secara terperinci.

\section{Manajeman Pembelajaran}

Pembahasan tentang konsep manajemen pembelajaran dapat ditelusuri dari pokok-pokok berikut ini, antara lain pengertian istilah manajemen, hakekat manajemen pembelajaran, pengertian manajemen pembelajara. Menelusuri dari sudut etimologi, dijelaskan bahwa istilah manajemen berasal dari bahasa Latin, yaitu manus atau mano atau mantis yang berarti tangan dan agere berarti melakukan. Selanjutnya dua istilah (manus dan agere) kemudian digabungkan menjadi satu istilah yang mengandung kata kerja, managere, yang berarti menangani, mengurus, mengelola. Istilah managere selanjutnya diterjemahkan kedalam bahasa Inggris berbentuk kata kerja menjadi "to manage" dengan kata benda " management " dan manager untuk orang yang melakukan kegiatan manajemen (Usman, 2009; Karwati \& Priansa, 2014). Manajemen dalam arti luas, adalah perencanaan, pengorganisasian, pengarahan dan pengendalian semua sumber daya milik organisasi untuk mencapai tujuan secara efektif dan efisien.

\section{Hakekat Manajemen Pembelajaran}

Manajemen merupakan suatu aktivitas manusia yang dapat dijumpai dalam setiap organisasi formal, baik yang sederhana sifatnya maupun sampai pada organisasi yang kompleks, organisasi pemerintah, dan swasta, termasuk organisasi pendidikan, organisasi bisnis maupun organisasi nir laba. Penjelasan ini diperkuat oleh pemikiran/penjelasan dari Megginson, Mosley \& Piettri (1983) tentang hakekat manajemen. "In fact, every time two or more people interact to achieve a common objective, an organization exist. And management is needed in all organization families and clubs, small business and large one, public and privat organization, profite - oriented and non-profite organization, manufacturing firm, service organization, etc".

Manajemen adalah kegiatan yang selalu dijumpai di dalam suatu aktivitas organisasi dan setiap organisasi itu memiliki tujuan. Untuk mencapai tujuan organisasi, diperlukan dan dimanfaatkan beberapa komponen. Supaya setiap komponen itu memberikan fungsi dan maknanya secara efektif dalam mencapai tujuan organisasi, maka diperlukan manajemen pengelolaan yang efektif pula. Dapat diperoleh gambaran mengenai apa sesungguhnya manajemen itu. Magginson, Mosley \& Piettri (1983) menjelasan pengertian manajemen sebagai berikut. "Management can be defined as working witth human, financial, and physical resources to achieve organizational objective by performance planning, organizing, leading, and controlling function ". Terjemahan bebasnya bahwa manajemen dapat diartikan sebagai suatu aktivitas kerjasama sejumlah orang dengan menggunakan sumber daya keuangan, dan fasilitas fisik lainnya untuk mencapai tujuan organisasi. Proses kerjasama itu nampak dalam fungsi-fungsi perencanaan, penorganisasian, kepemimpinan, dan pengawasan. Hersy \& Blanchard (1977) juga menjelaskan konsep manajemen sebagai proses kerjasama dengan dan melalui orang-orang dalam kelompok untuk mencapai tujuan organisasi (Abubakar, Elrehail, Alatailat, \& Elçi, 2019). Selanjutnya dengan berpijak pada perspektif proses, maka Wagner \& Hollenbeck (1992) merumuskan pengertian manajemen sebagai berikut: " management is thus a process of planning, organizing, directing, and controlling organizational behaviors in order to accomplish a mission through the division of labor ". Manajemen itu adalah suatu proses kegiatan yang 
dilakukan oleh pimpinan dan anggota organisasi dalam bentuk perencanaan program, pengorganisasian unit-unit kerja untuk melaksanakan program, mengarahkan dan mengawasi perilaku manusia yang bekerja supaya seluruh kekuatan hanya terfokus pada upaya realisasi atau pencapaian visi dan tujuan organisasi.

Ada beberapa konsep yang mendapat penekanan yang sama dalam tiga sumber, yaitu ada proses kerjasama yang melibatkan sejumlah orang, aktivitas yang dikerjakan, tujuan atau visi organisasi yang dicapai, dan ada seperangkat sumberdaya yang dikelola dan digunakan melalui proses perencanaan, pengoranisasian, pengawasan, pengendalian, dan evaluasi atas hasil yang dicapai.

Bertumpu pada urian tentang manajemen, maka hakekat manajemen pendidikan adalah pengelolaan dan pelaksanaan seperangkat tugas-tugas pendidikan, pembelajaran secara efektif dan efisien melalui proses perencanaan, pengorganisasian, pelaksanaan, penilaian dan evaluasi untuk mencapai tujuan pendidikan sekolah.

\section{Prinsip Manajemen Pembelajaran}

Rumusan prinsip-prinsip manajemen menurut McGregor (1960) sebagai berikut.

a) Memperioritaskan tujuan ujuan pendidikan di atas kepentingan pribadi dan kepentingan kelompok. Melalui prinsip manajemen demikian, segala sumber daya dan strategi kerja dipertaruhkan hanya bagi mencapai/mewujudkan visi/tujua pendidikan/pembelajaran.

b) Mengkoordinasikan wewenang dan tanggung jawab; manajmen diperlukan untuk mengatur dan menjaga agar aspek wewenag, tanggung jawab, hak dan kewajiban, terlaksana secara seimbang dan harmonis. Jika wewenang dan hak didahulukan dan mengabaikan tanggung jawab dan kewajiban, maka pasti timbl masalah dan konflik yang menyebabkan ketidakoptimalan dalam mencapai tujuan pendidikan.

c) Perhatian penuh kepada staf dalam kaitan dengan pemberian tugas dan tanggung jawab. Pimpinan mendelegasikan dan memberikan wewenang dan tanggung jawab kepada stafnya, perlu memperhatikan kemampuan dan sifat responsibility dari staf yang bersangkutan. Termasuk disini adalah menenal karakter dan kepribadian.

d) Revitalisasi nilai-nilai; orgasasi selalu melibatkan sejumlah orang. Setiap anggota organisasi itu memiliki nilai, pandangan hidup dan cita-cita tertentu. Juga system niliai yang dianutnya. Tugas dan tanggung jawab manajemen adalah menjaga, memelihara dan mengembangkan nilai-nilai psitif yang mendukung kebehasilan kerja dan pencapaian tujuan organisasi. Sedangkan sistem nilai yang menghambat individu untuk berkembang, perlu diperhatikan untuk dieliminir.

\section{Hakekat Kurikulum dan Pembelajaran}

\subsection{Konsep Kurikulum}

Ditinjau dari konsep makro, maka kurikulum pembelajaran dipahami sebagai seluruh aktivitas yang dilakukan di sekolah baik dalam maupun di luar kelas yang memberikan pengalaman belajar kepada siswa, termasuk didalamnya adalah bahan pembelajaran. Leonard \& Utz (1974) menjelaskan konsep makro kurikulim sebagai berikut: "Curriculum is more than the more formalized learning of the subject matter. It involves all the learning that takes place in a school. It represents the learning climate, interpersonal relationships, and subject matter materials and their incorporation by the students into his cognitive and affective development. This view of curriculum agrees with that of Fred Wilhelms, who says that curriculum is not so much the stuff to 
be taught but the stuff to be used “. Terjemahan bebasnya sebagai berikut: " Makna kurikulum dalam konteks makro, adalah lebih dari pada sekedar bahan pelajaran yang dipersiapkan dan diajarkan kepada anak didik di kelas. Kurikulum dalam konteks makro, mencakup semua aktivitas yang dikerjakan di sekolah yang memberikan pengalaman belajar kepada siswa. Misalnya budaya dan iklim belajar di sekolah, hubungan antar pribadi, tetapi juga bahan pelajaran yang dipelajari siswa untuk mengembangkan aspek pengetahuan, sikap dan juga keterampilannya.

Istilah kurikulum dikembangkan dari istilah Latin: curricula, kemudian menjadi

curere, Istilah curere kemudian diembangan menjadi kurir. Kurir berarti pembawa berita atau pesan dari seseorang kepada orang lain dan ada respons atau tindakan yang dilakuan oleh penerima pesan sebagai hasil dari isi pesan yang dibawa kurir. Pengertian ini kemudian diangkat dan diterapkan dalam dunia pendidikan yang dikenal dengan istilah kurikulum. Makna yang terkandung dalam konsep curere/curricula itu adalah bahwa guru atau pendidik membawa pengetahuan yang dikemas dalam bentuk kurikulum atau pembelajaran itu ke kehidupan peserta didik sebagai pengetahuan dan pengalaman baru yang mendorongnya ke arah pertumbuhan dan perkembangan menuju tingkat kedewasaan yang semestinya. Konsep makro kurikulum pembelajaran dalam tataran konsep dan implementasi dapat mencakup berbagai aktivitas di sekolah, misalnya iklim sekolah, hubungan antar pribadi dikalangan warga sekolah, kerjasama siswa dalam membentuk kelompok belajar guna mengembangkan pembelajaran khususnya aspek pengetahuan dan sikap (Gemnafle, Waimuri \& Batlolona, 2018).

\subsection{Postur Kurikulum Pendidikan Nasional}

Mungkin saja telah dilakukan berbagai kajian ilmiah berupa penelitian untuk menganalisis hubungan antara kurikulum dengan mutu output pendidikan di Indonesia, namun hasilnya belum dipublikasikan kepada halayak. Berbicara tentang masalah mutu pendidikan, maka hal yang mengambil posisi sebagai salah satu komponen penentu adalah kurikulum dalam arti makro maupun yang mikro. Selain kurikulum, ada pula variabel penentu yang lain adalah guru dan dosen. Pembicaraan tentang mutu pendidikan di Indonesia belum ada informasi baru yang cukup menggembirakan bahwa masalah mutu pendidikan dan ekonomi telah menggeser negara-negara lain di kawasan Asia Tenggara misalnya Singapura dan Malaysia yang mengambil posisi atas dan Thailand juga bergerak maju (Litsareva, 2017). Dalam waktu beberapa dekade terakhir ini, para penentu kebijakan di Indonesia hanya memfokuskan perhatian kepada aspek jumlah cenderung mengabaikan mutu. Berbagai usaha yang dilakukan belum membawa perubahan yang signifikan, termasuk revisi kurikulum pendidkan nasional secara periodik.

Salah satu hal yang belum dikaji, dianalisis, dikembangkan dan dilaksanakan secara baik adalah kurikulum. Postur kurikulum ibarat manusia yang berpostur gemuk tapi tidak sehat. Tidak mampu mengangkat beban berat. Lebih cenderung berperilaku negatif dari pada berbuat positif. Secara mikro, ada mata pelajaran yang diajarkan di tingkat Sekolah Dasar sampai di tingkat perguruan tinggi, namun efeknya yang nyata dalam diri output pendidikan kurang terlihat. Misalnya mata pelajaran Agama, Pendidikan Kewargaan Negara dan Bahasa Indonesia. Secara kasar dapat dicatat bahwa setiap orang yang belajar mulai dari SD sampai dengan perguruan tinggi, disediakan waktu terjadwal formal tiap mata pelajaran hampir 500 jam untuk mempelajari mata pelajaran-mata pelajaran tersebut. Namun kenyataan menunjukkan bahwa masih ada manusia di Indonesia yang berprilaku destruktif, rasa nasionalismenya semakin menipis 
dan penggunaan bahasa yang tidak tertata secara baik dan benar dalam mengungkap pikirannya baik tertulis maupun lisan.

Sudah saatnya para ahli dalam bidang pendidikan duduk bersama, berpikir dan berkarya memproduksikan suatu kurikulum pembelajaran yang tidak terlampau dan membebani siswa sehingga dapat menimbulkan konflik kognitif, afektif dan psikomotorik. Para ahli pendidikan harus menghasilkan suatu kurikulum yang mampu membawa siswa kita senang dan selalu gembira dalam mengikuti dan melakukan seluruh kegiatan belajarnya. Tidak memandang sekolah sebagai penjara bagi dirinya dalam proses pertumbuhan dan perkembangannya. Dengan begitu " kita tidak terjebak dalam suatu sistem, format dan proses pendidikan dan pembelajaran yang akan melahirkan lulusan yang output dan outcome yang bermental tukang dan pegawai yang miskin imajinasi dan lemah karakter. Pendidikan harus membebaskan manusia dari rasa takut, tertekan, harus bersifat emansipatif dan liberatif, membebaskan manusia dari kebodohan, ketertinggalan, penindasan, dan dari berbagai hal yang membelenggu manusia dalam meraih pertumbuhan dan perkembangan yang optimal. Kurikulum yang berlaku dan diterapkan dalam proses pembelajaran mulai dari pendidikan dasar hingga pendidikan menengah umum dan kejuruan saat ini perlu dikaji kembali. Termasuk semua perangkat pendukungnya, misalnya guru dan fasilitas pembelajaran.

\subsection{Guru sebagai Pelaksana Kurikulum}

Pencapaian hasil pembelajaran yang maksimal atau memuaskan, banyak ditentukan oleh Guru. Posisi Guru dalam proses penyelenggaraan pembelajaran di sekolah tidak dapat digantikan oleh sumber-sumber pembelajaran yang lain berupa tekologi. Di zaman modern saat ini, dimana didukung oleh kemajuan ilmu pengetahuan dan teknologi yang sangat canggih, termasuk kemajuan di bidang teknologi informasi, dapat menggeser pola kerja manual dengan sistem digital, sangat memungkinkan seseorang dapat melakukan kegiatan pembelajaran secara mandiri dengan mengacu pada panduan proses pembelajaran yang telah terprogram. Dalam memasuki tahapan pembelajaran, maka memanfaatkan perangkat pembelajaran berbasis teknologi, kedudukan dan peran guru sebagai fasilitator. Melakukan kegiatan pembelajaran dengan menggunakan strategi dan pendekatan yang berbasis teknologi dimaksud ini nampaknya mengambil alih peran guru dalam mentrasformasikan ilmu pengetahuan dan bahkan memungkin siswa untuk aktif dan kreatif melakukan aktivitas belajarnya dan sekaligus mencari dan menemukan sendiri ilmu pengetahuan yang diminatinya. Kendatipun demikian, peran guru dari sisi yang lain tidak dapat digantikan. Pengaruh hubungan manusiawi yang menyertakan keteladanan dan pandangan tentang nilai-nilai hidup manusia tidak dapat dijelaskan dan diperoleh melalui pola pembelajaran berbasis teknologi tersebut. Dengan demikian kehadiran dan peran Guru dalam proses pembelajaran menjadi sangat penting dan bermakna dalam mempersiapkan suatu generasi muda secara utuh yang berkualitas sejak dahulu, sekarang dan esok sangat sentral dan strategis.

Guru yang mengajarkan berbagai ilmu pengetahuan di era modern saat ini dan di masa yang akan datang, tidak dibatasi, bahkan menjadi keharusan. Namun hal yang sangat penting dan diharapkan mendapat tempat mutlak sebagai tujuan pembelajaran adalah guru harus mampu mengembangkan bahan pembelajaran yang memungkinkan peserta didik mencapai perubahan perilaku konstruktif dari dalam diri siswa. Hasil pembelajaran demikian menghendaki guru harus memiliki dan mengaplikasikan berbagai komptensi dasar yang dimilikinya secara optimal guna meraih kualitas 
pembelajaran yang membebaskan siswa dari bebagai keterbatasan yang membebani pengembangan kompetensinya (Leonard \& Utz, 1974 ). Guru dan dosen dikategorikan pada tataran orientasi tugas dan tanggung jawab yang mencirikan profesionalisme kerja sebagai pendidik dan pembelajar terpercaya, terampil, memiliki pandangan dan arah hidup yang jelas, tata nilai dan tujuan hidup serta keyakinan yang teguh, yang mengacu kepada pengetahuan, sikap dan keterampilan yang dimiliki (Azer, 2005).

\subsection{Kurikulum Pembelajaran di Zaman Modern}

Salah satu mata pelajaran yang dipelajari siswa sejak sekolah dasar sampai perguruan tinggi adalah mata pelajaran agama. Menjadi pertanyaan adalah sejauh mana efek pembelajaran agama terhadap kualitas moral dan kehidupan spiritual siswa? Serta bagaimana kontribusinya dalam membangun kualitas perilaku dan karakter manusia yang telah mempelajarinya? Kenyataan menunjukkan bahwa sebagian besar warga negara kita belum mampu memproteksi diri dari rayuan yang menyeret mereka ikut melakukan hal-hal yang tidak wajar dan tak layak dilakukan oleh manusia yang mengklaim dirinya sebagai orang yang menjalankan ajaran agamanya secara baik dan benar dalam hidup kesehariannya. Kendatipun tindakan itu masih dalam kategori kecil dan tidak diketahui oleh orang lain. Ini berarti ada yang salah dalam proses transformasi nilai-nilai hidup yang diajarkan dalam kitab suci masing-masing. Nilai-nilai positif dalam mata pelajaran agama yang dipelajari di pendidikan hingga di perguruan tinggi belum menghasilkan integritas pribadi seseorang, atau belum ditransformasikan dengan baik dan mungkin pula kurang diinternalisasikan oleh siswa.

Terhadap permasalahan belum maksimalnya dampak kurikulum dan pembelajaran agama dan juga mata pelajaran yang lain terhadap perilaku konstruktif manusia Indonesia, maka diduga ada beberapa hal mendasar sebagai penyebabnya. Halhal mendasar dimaksud adalah antara lain struktur kurikulum, manajemen pembelajaran yang dipersiapkan, strategi dan proses implementasinya, guru sebagai komponen pelaksana sekaligus penentu hasil belajar siswa. Dalam memasuki era modern saat ini dan di masa depan, kurikulum pembelajaran perlu dilihat kembali yang didalamnya mencakup pula strategi mengajar, komptensi, komitmen serta kecakapan kerja guru dan dosen yang terus diperbaiki terutama dalam mengembangkan dan merumuskan tujuan pembelajaran dan mengembangkan bahan ajarnya. Strategi dan pendekatan pembelajaran modern namun bertumpu pada nilai-nilai tradisonal positif yang patut dikaji dan diterapkan dalam pembelajaran di sekolah (Bencsik, Juhász, \& HorváthCsikós, 2016). Sistem pengelolaan pembelajaran yang diterapkan hendaknya merujuk kepada manajemen modern diantaranya penerapan manajemen strategi dan manajemen kualitas total (Stukalina, 2010). Strategi pembelajarannya hendaknya difokuskan kepada keaktifan, misalnya inquiry dan expository learning (Lazonder \& Harmsen, 2016).

Selain pengelolaan dan strategi pembelajaran modern yang diaplikasikan untuk memperbaiki dan meningkatkan keefektifan pembelajaran di sekolah, ada pula komponen penting dan menentukan jalannya proses pembelajaran serta hasil maksimal yang dicapai, adalah guru itu sendiri. Guru merupakan komponen kunci dalam kaitan dengan mutu pembelajaran(Smith \& Benavot, 2019). Untuk itulah masalah rendahnya mutu pendidikan di Indonesia pada semua aras dan jalur pendidikan yang hingga saat ini belum ditemukan penyelesaiannya, terletak pada pundak guru dan dosen sebagai salah satu komponen penentu. Rendahnya mutu pendidikan di Indonesia akan senantiasa dikaitkan dengan rendahnya mutu tenaga pengajar dan rendahnya mutu 
lembaga kependidikan yang menghasilkan calon guru (Martin, 2019). Oleh karena itu dalam menata kurikulum pembelajaran di sekolah di era modern saat ini untuk menjawab masalah rendahnya mutu pendidikan di Indonesia adalah menata kembali sistem rekrutmen, proses penyiapan sampai kepada sistem perawatan guru di Indonesia dan mengantarkan siswa pada minat dan bakat sejak dini. Melalui strategi inovasi dan rekonstruksi pendidikan tenaga guru yang tepat, mutu pendidikan di Indonesia pasti mengalami peningkatan secara bertahap di waktu yang akan datang.

\section{Manajemen Kurikulum dan Program Pembelajaran}

Para ahli manajemen pendidikan berpendapat bahwa setiap kegiatan dalam organisasi formal pendidikan, tentu memerlukan aktivitas manajemen, termasuk aktivitas penataan, penyusunan dan pengembangan serta pelaksanaan kurikulum dan pembelajaran di suatu sekolah (Khan \& Law, 2015). Oleh karena itu dalam kaitan dengan manajemen kurikulum dan program pembelajaran, mencakup kegiatan-kegiatan yang meliputi perencanaan, pelaksanaan, dan evaluasi dan tindak lanjut (Mulyasa, 2003) dan guru sebagai pelaksana manajemen pembelajaran.

\subsection{Perencanaan Pembelajaran Efektif}

Pencapaian hasil pembelajaran yang maksimal ditentukan oleh proses perencanaan yang matang dan efektif. Proses perencanaan yang efektif ditentukan pula oleh kemampan dan pemikiran sistemik dari seorang guru yang memungkinkan dapat diprediksikan dan ditetapkan hal-hal penting dan strategis yang akan dilaksanakan dalam proses belajar mengajar. Perencanaan kurikulum dan bahan pembelajaran yang efektif dan bermakna penting dalam mencapai hasil pembelajaran yang maksimal dilakukan oleh para guru yang berkualitas dan memiliki kemampuan profesionalisme yang tinggi. Itulah sebabnya orang pada umumnya menyimpulkan bahwa hasil pembelajaran yang maksimal dikendalikan oleh guru yang berkualitas tinggi.

Perencanaan pembelajaran meliputi proses penyusunan materi, media, pendekatan dan metode, serta penilaian dalam suatu alokasi waktu yang akan dilaksanakan pada suatu masa tertentu untuk mencapai tujuan yang telah ditentukan. Jika seorang guru hendak dan sedang menyusun dan mempersiapkan bahan ajar, maka ada beberapa hal penting yang diperhatikan dan dikerjakan, yaitu menyusun dan mengembangkan isi materi, menetapkan tujuan pembelajaran yang akan dicapai, memilih dan menetapkan metode dan media pembelajaran yang akan diikuti dan digunakan, merumuskan instrumen atau alat evaluasi dalam berbagai bentuk yang digunakan untuk mengukur tingkat pencapaian tujuan pembelajaran.

Pada dasarnya konsep operasional perencanaan pembelajaran adalah sejalan dengan konsep operasional perencanaan yang lazim dilakukan dan diikuti pada proses kerja organisasi formal lainnya, yaitu menetapkan tujuan yang akan dicapai, merumuskan berbagai kegiatan yang relevan untuk mendukung tercapainya tujuan, jangka waktu yang diperlukan dalam melakukan suatu aktivitas, cara kerja dan atau strategi kerja yang diikuti dan instrumen yang disediakan untuk mendukung operasionalisasi kegiatan untuk mencapai tujuan yang diharapkan. 


\subsection{Implementasi Pembelajaran}

Mengacu pada rencana pembelajaran yang telah disusun dan disahkan oleh Kepala Sekolah sebagai panduan dalam mengajar, maka seorang guru dapat terbantu untuk melasanakan tugasnya secara profesional dan operasional. Rencana program pembelajaran yang akan dilaksanakan didalamnya memuat beberapa komponen yang membantu guru untuk melaksanakan tugas mengajar secara efektif berupa program sekolah, silabus, rencana pelaksanaan pembelajaran, rencana tindak lanjut yang merupakan aktivitas pembelajaran pengayaan dan program remedial bagi siswa yang belum mencapai kompetensi yang diharapkan. Salah satu aspek penting yang diperhatikan dalam tahap implementasi kurikulum dan pembelajaran di kelas adalah suasana dan kondisi siswa yang siap untuk menerima pembelajaran yang akan disajikan. Suasana kelas dan kondisi siswa yang diprediksi menjadi suasana yang mendukung proses pembelajaran yang berlansung lebih efektif adalah sebagaimana yang dikemukakan oleh Karwati \& Priansa (2014) sebagai berikut.

a) Suasana kelas yang kondusif; memiliki iklim yang positif bagi berlangsungnya kegiatan pembelajaran. Guru mampu menciptakan suasana belajar yang menyenangkan bagi siswa. Model dan metode pembelajaran yang diterapkan oleh guru lebih bersifat atraktif dan mampu merangsang daya kreativitas siswa.

b) Kelas yang tenang dan disiplin; guru yang terampil akan mampu menciptakan kelas yang tenang dan disiplin. Siswa patuh terhadap aturan yang ditetapkan oleh guru di kelas karena aturan dimaksud telah disetujui oleh siswa untuk diterapkan di kelas. Pelanggaran yang dilakukan oleh siswa dicatat, diberikan sanksi, dan dievaluasi untuk mengkaji efektivitasnya.

c) Kelas yang berlangsung secara alamiah; Kelas yang alamiah beroperasi dengan sendirinya. Guru menghabiskan sebagaian besar waktunya untuk melaksanakan tugasnya sebagai pembelajar. Siswa mampu mengikuti pembelajaran dengan mandiri tanpa pengawasan ketat yang dilakukan oleh guru. Siswa yang terlibat dalam proses belajar, aktif untuk saling berinteraksi. Pelaksanaan program dan proses pembelajaran yang berlangsung dalam suasana kelas yang kondusif, tenang, alamiah dengan disiplin yang tinggi dan bertumpu pada sistem manajemen pembelajaran yang efektif, diyakini akan membuahkan hasil belajar yang optimal dalam berbagai bidang pengetahuan. Suasana dan iklim pembelajaran sebagaimana dikemukakan di atas sebenarnya bersumber dari beberapa faktor pendukung yang berkorelasi positif dengan kepemimpinan Kepala Sekolah yang kuat, terbuka, efektif dan profesional. Selain itu para guru di sekolah memiliki komitmen dan disiplin kerja yang tinggi.

\subsection{Evaluasi Hasil Belajar}

Salah satu aktivitas yang menjadi perhatian dalam pekerjaan manajemen pembelajaran adalah evaluasi hasil belajar siswa. Masalah manajemen pembelajaran yang berkaitan dengan evaluasi hasil belajar adalah guru yang menyusun program pembelajaran menetapkan cara yang dilakukan untuk mengecek sejauh mana peserta didik telah dapat menerima, mencerna, memahami menguasai dan menggunakan isi pengetahuan dalam materi pelajaran yang diajarkan oleh guru.

Ada beberapa cara evaluasi yang diusulkan untuk digunakan oleh guru dalam mengukur ketercapaian kompetensi sebagai berikut. 1) kompetensi kognitif, digunakan cara evaluasi tes lisan, tes tertulis, observasi dan pemberian tugas. 2) kompetensi afektif 
digunakan cara evaluasi tes lisan, tes skala sikap, pemberian tugas observasi, ekspresif dan proyektif. 3) kompetensi keterampilan, digunakan cara evaluasi observasi, tes tindakan, dan tes lisan. Bentuk-bentuk evaluasi hasil belajar demikian diatur dalam empat macam tes berupa pre test, post test, summative test dan formative test.

\subsection{Guru sebagai Pengelola Pembelajaran}

Berbagai aktivtas yang dlakukan oleh guru dalam kaitan dengan pengelolaan pembelajaran mencakup merencanakan bahan pembelajaran, merumuskan tujuan pembelajaran, mengorganisasikan dan mengembangkan bahan pembelajaran, menjalin komunikasi yang harmonis dengan kepala sekolah, menertibkan kelas, mempresentasikan bahan ajar, membangun dan menjaga relasi dan komunikasi edukatif yang konstruktif dengan peserta didik, memberi motivasi dan membangun semangat belajar para siswa, mengevaluasi dan menindaklanjuti hasil belajar peserta didik.

Guru yang terampil dan profesional, wajib melaksanakan tugas dan fungsi manajemen yang disebutkan sebelumnya. Keberhasilan guru dalam mengembangkan kemampuan kognitif, afektif dan psikomotorik siswa secara optimal, dipengaruhi pula oleh kualitas dan kontinuitas pelaksanaan fungsi-fungsi manajemen pembelajaran. Hal demikian menuntut pula guru-guru yang profesional dan memiliki komitmen pelayanan yang tinggi dan konsisten.

\section{Kepala Sekolah sebagai Pemimpin Pembelajaran}

Pembahasan tentang peran kepala sekolah sebagai pengelola pembelajaran lebih menyoroti peran dan tugasnya dalam menjalankan kepemimpinan di sekolah. Dalam menjalanan tugas inilah yang memberikan peluang kepada kepala sekolah untuk mempengaruhi, mengarahkan dan mendorong guru untuk melaksanakan tugas mengelola pembelajaran di sekolah. Dengan demikian dapat dipahami bahwa kepala sekolah melaksanakan tugas sebagai pemimpin dan pengelola pembelajaran itu diatur melalui guru di sekolah.

\subsection{Pengertian Kepemimpinan Pembelajaran}

Definisi kepemimpinan pembelajaran banyak dijumpai di dalam berbagai literatur manajemen pendidikan. Berbagai definisi dimaksud secara keseluruhan mengandung makna yang sama, yaitu kemampuan seorang pemimpin yaitu kepala sekolah untuk mempengaruhi perilaku orang guru dan siwa dalam melakukan kegiatan yang berkaitan dengan proses pembelajaran menuju kepada pencapaian tujuan sekolah. Kepemimpinan pembelajaran adalah kemampuan seseorang dalam membimbing, mempengaruhi dan mengarahkan untuk melaksanakan kegiatan mengajarnya secara efektif dan mencapai kepuasan profesionalisme (Lamb, Martin-Misener, BryantLukosius, \& Latimer, 2018).

Di bawah arahan kepala sekolah dan guru dapat dengan leluasa mengembangkan dan menemukan sendiri modeldan strategi kerja yang mendukung pencapaian hasil belajar yang maksimal sesuai tujuan dan memungkinkan dapat mengembangkan dan menemukan sendiri cara atau model pendekatan yang sesuai dengan kondisi siswa yang telah lama digelutinya. Sergiovanni (1987) menghubungkan penjelasan atas konsep kepemimpinan pembelajaran dengan pengelolaan sekolah yang sukses, yaitu seorang kepala sekolah atau seorang guru yang memperlihatkan kemampuan, cita-cita dan, 
keterampilan manajerial yang tangguh, yang menjamin tersedianya iklim kerja yang mendukung usaha pencapaian tujuan sekolah.

Kepemimpinan pembelajaran pada dasarnya mengacu kepada konteks pendidikan yaitu kemampuan untuk mempengaruhi orang-orang atau kelompok orang dengan maksud untuk mencapai suatu tujuan (Luyten \& Bazo, 2019). Perbedaannya adalah bahwa kepemimpinan pembelajaran lebih berfokus secara khusus kepada situasi proses pembelajaran itu terjadi, mulai dari tahap perencanaan, pelaksanaan dan pada akhirnya pada tahap evaluasi hasil kegiatannya. Di sini terlihat ada kemampuan yang memancar dari seseorang pemimpin untuk mempengaruhi, mengajak dan membawa orang lain yang terlibat secara serius dalam proses belajar yang terjadi sehingga tercapailah hasil maksimal sesuai tujuan yang telah ditetapkan.

\subsection{Kompetensi Kepemimpinan Pembelajaran}

Smith \& Andrews (1987) mengemukakan empat kompetensi dasar yang harus dimiliki seorang pemimpin pembelajaran yaitu, 1) kemampuan untuk memiki pemahaman yang jelas tentang tujuan sekolah serta proses pencapaian tujuan dimaksud. 2) Kemampuan untuk mengarahkan dan mengatur guru-gurunya agar hanya memusatkan perhatian, tenaga dan waktu kepada pencapaian tujuan sekolah. Termasuk disini adalah kemampuan merangsang dan memotivasi guru-guru agar mereka dapat mengembangkan dan mengaktualisasikan kemampuannya yang masih bersifat potensial, sehingga mereka lebih berhasil dalam membelajarkan anak didiknya. 3) Kemampuan menampilkan perilaku kerja yang menyenangkan, suatu hal yang sangat prinsipil yang dipegang teguh oleh setiap pemimpin pembelajaran dalam mengelola seluruh aktivitas yang terkait dengan proses belajar mengajar adalah bersikap jujur, terbuka dan ramah, baik terhadap guru-guru, staf administrasi serta melibatkan sepenuhnya dalam segala hal yang terkait dengan urusan sekolah. 4) Kemampuan untuk mengenal dan memahami diri sendiri. Seorang pemimpin pembelajaran perlu memahami dengan baik semua kekuatan, kemampuan, kelebihan dan kelemahan serta keterbatasan yang melekat pada dirinya. Dengan memahami kelebihan dan keterbatasanya seorang pemimpin dapat menata dan menempatkan diri secara tepat di antara guru-guru, pegawai, siswa dan bahkan semua pihak yang terkait dengan urusan di sekolah yang dipimpinnya. Menata diri sendiri untuk melakukan berbagai upaya untuk mengembangkan dan mengaktualisasikan kekuatan atau kelebihan yang dimiliki dan mengaplikasikan dalam tugas kepemimpinan. Di samping itu dapat pula melakukan berbagai upaya untuk meminimalkan keterbatasannya sehingga tidak menghambat dalam mengembang tugas kepemimpinan.

Keempat kompetensi kepemimpinan pembelajaran yang dikemukakan dapat dipahami berbagai variabel yang cukup signifikan terhadap perilaku kepemimpinan pembelajaran dalam mengendalikan semua komponen dan aktivitas yang berkaitan langsung dengan proses pembelajaran di sekolah (Lipham et al, 1985). Jika seorang pemimpin pembelajaran mampu mengaktualisasikan dan mengembangkan kompetensinya secara efektif, maka terjadi peluang yang baik untuk mencapai prestasi belajar para siswa yang maksimal. 


\subsection{Karakteristik dan Perilaku Pemimpin Pembelajaran}

Mengacu kepada hasil penelitian beberapa ahli manajemen pendidikan, Smith \& Andrews (1987) mengajukan beberapa hal yang merupakan karakteristik pemimpin pembelajaran yang ditunjukan pada Gambar 1 .

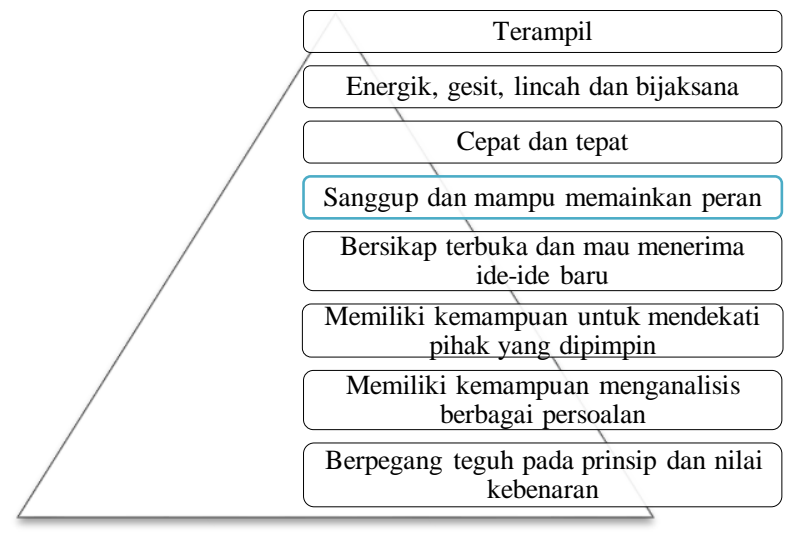

Gambar 1. Karakteristik pemimpin pembelajaran

Di samping butir-butir karakteristik yang menggambarkan sosok seorang pemimpin pembelajaran tersebut di atas, dikemukakan pula beberapa hal yang dapat dilakukan dan sekaligus mencerminkan perilaku nyata dari seorang pemimpin pembelajaran (Smith dan Andrews, 1987 ) sebagaimana ditunjukkan pada Gambar 2.

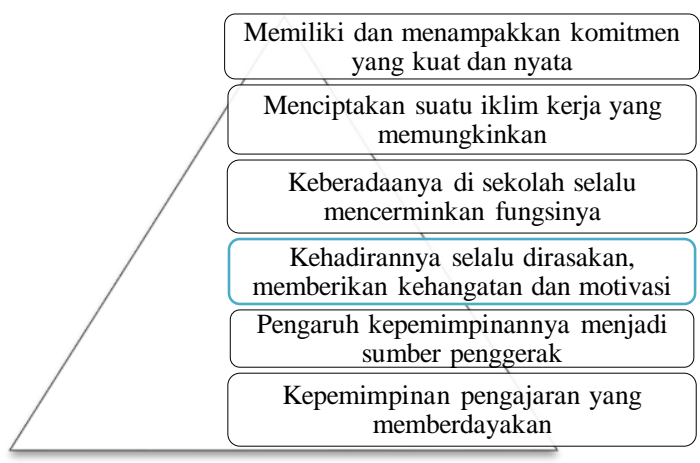

Gambar 2. Karakteristik pemimpin pembelajaran yang mencerminkan perilaku nyata

Pengembangan kemampuan staf yang menjadi pusat orientasi kepemimpinan pembelajaran dilakukan dengan bertitik tolak dari asumsi bahwa pada dasarnya setiap orang yang terlibat dalam suatu organisasi pendidikan berupa sekolah. Jika diarahkan dan dimanfaatkan dengan sebaik-baiknya dalam kerjasama, maka diperoleh hasil kerja yang maksimal pula. Seorang pemimpin pembelajaran perlu mengembangkan kemampuan guru dan siswa semaksimal mungkin sebagai upaya untuk mencapai hasil belajar siswa sesuai target dan cita-cita yang disepakati bersama (Sergiovanni, 1987; Smith \& Andrews, 1987; Lipham et al., 1985). 


\subsection{Pengembangan Kepemimpinan Pembelajaran}

Salah satu upaya yang terus menerus dilakukan oleh seorang pemimpin pembelajaran adalah perlu tampil lebih prima dan lebih efektif dalam mengendalikan dan menggerakkan berbagai aktivitas pembelajaran di sekolah. Itu berarti pemimpin pengajar yang telah ditetapkan sebagai acuan dasar dalam aktivitasnya. Seorang pemimpin pembelajaran yang berhasil dilengkapi dengan upaya serius dalam memimpin guru-guru dalam mengoperasionalisasikan program pembelajaran di kelas secara efektif dan selanjutnya berdampak positif terhadap hasil belajar siswa. Ini merupakan indikasi dari keberhasilan dalam mengembangkan kompetensi kerja dari para. Mengembangkan kompetensi dan mentransformasikan berbagai kompetensi dan keterampilan yang dimilikinya termasuk upaya mengembangkan dan menumbuhkan sikap kreativitas, semangat dan disiplin kerja yang tinggi dari guru-guru adalah wujud nyata upaya pengembangan kepemimpinan pembelajaran oleh seorang kepala sekolah. Transformasi kompetensi atau kesanggupan dan keterampilan secara efektif kepada guru, diharapkan mempengaruhi perilaku siswa secara efektif dalam belajar.

\subsection{Model Kepemimpinan Pembelajaran}

Model kepemimpinan pembelajaran ditunjukan pada Gambar 3.

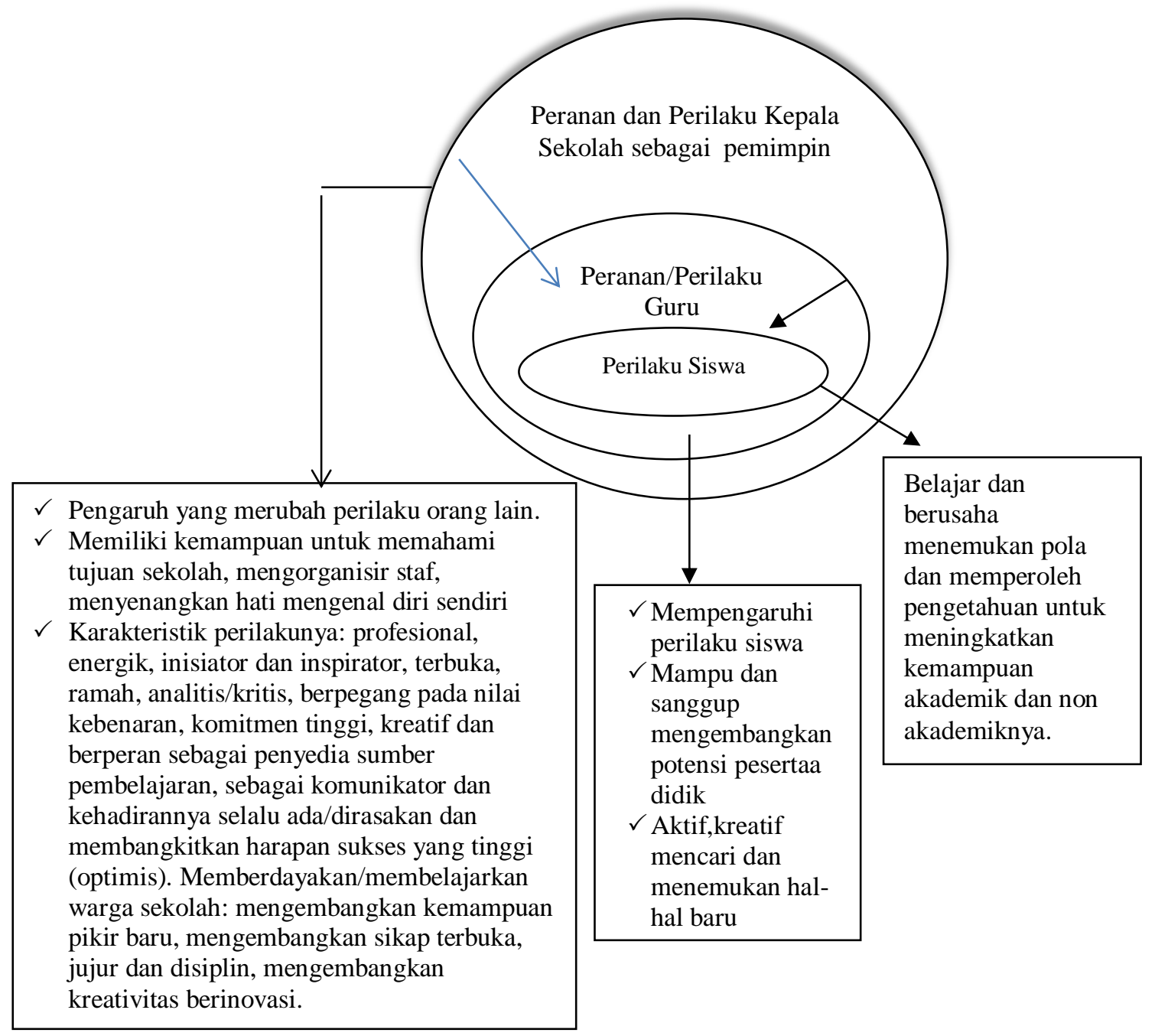

Gambar 3. Model kepemimpinan pembelajaran 
Kepemimpinan pembelajaran yang efektif sangat diperlukan untuk membawa perubahan yang signifikan bagi hasil belajar siswa. Sebagaimana telah dijelaskan pada uraian sebelumnya nampak bahwa kepemimpinan pembelajaran yang terjadi dalam suatu proses pembelajaran sebenarnya terkait langsung dengan tiga komponen utama, yakni pemimpin pembelajaran berupa kepala sekolah dan atau guru senior, guru-guru dan siswa. Setiap komponen tersebut diharapkan dapat memainkan perananya secara maksimal dalam proses pembelajaran yang berlangsung. Di samping itu peranan mereka masing-masing diperkuat pula oleh komponen non manusia berupa fasilitas pembelajaran, laboratorium, perpustakaan, lingkungan sekitar sekolah dan lain-lain. Semuanya memiliki peranan yang nyata dalam mencapai hasil belajar yang tinggi, baik akademik maupun non akademik yang berupa peningkatan daya pikir, peningkatan daya kalbu, dan peningkatan daya fisik dapat terwujud (Slamet, 2000).

\section{KESIMPULAN}

Pada bagian akhir dari kajian mengenai pengembangan kepemimpinan pembelajaran ini, akan disajikan beberapa pemikiran praktis untuk menggarisbawahi seluruh telaah konsep pengembangan kepemimpinan pembelajaran dan dampaknya terhadap prestasi belajar siswa. Hal-hal yang dimaksud adalah sebagai berikut. 1) Kemampuan manajerial, yaitu kesanggupan memahami dan mengimplementasikan konsep-konsep manajemen pendidikan, khususnya kepemimpinan pembelajaran sebenarnya merupakan salah satu hal yang amat menentukan mutu pelayanan pendidikan sehingga lembaga sekolah menampakan posisi sebagai suatu lembaga pendidikan yang berkualitas dan diminati oleh masyarakat luas atau sekolah itu menarik hati masyarakat, terutama siswa yang belajar atau mengikuti pembelajaran sehari-hari di dalamnya. 2) Konsep-konsep kepemimpinan pembelajaran yang dipraktikan atau diimplementasikan oleh kepala sekolah selaku pemimpin pembelajaran, ditempatkan pada pemahaman dan upaya mengembangkan kompetensi guru dan jika kompetensi guru dikembangkan dan bertumbuh secara baik, maka guru yang bersangkutan akan menampilkan semangat dan komitmen baru yang akan terjadi termasuk didalamnya adalah kemampuan guru dalam mengelola pembelajaran karena guru merasa didukung sepenuhnya oleh kepala sekolahnya. 3) Jika kepala sekolah selaku pemimpin pembelajaran dan guru-guru selaku pemimpin pembelajaran mengembangkan dan memiliki komitmen yang tinggi dan pemahaman yang sama untuk meningkatkan mutu pembelajaran, maka peserta didik akan mencapai prestasi belajar yang semakin meningkat, baik itu prestasi akademik maupun prestasi non akademik.

\section{REFERENSI}

Abubakar, A. M., Elrehail, H., Alatailat, M. A., \& Elçi, A. (2019). Knowledge management, decisionmaking style and organizational performance. Journal of Innovation and Knowledge, 4(2), 104114. https://doi.org/10.1016/j.jik.2017.07.003.

Alvunger, D. (2015). Towards new forms of educational leadership? The local implementation of förstelärare in Swedish schools. Nordic Journal of Studies in Educational Policy, 2015(3), 30103. https://doi.org/10.3402/nstep.v1.30103.

Azer, S. A. (2005). The qualities of a good teacher: How can they be acquired and sustained? Journal of the Royal Society of Medicine, 98(2), 67-69. https://doi.org/10.1258/jrsm.98.2.67.

Bencsik, A., Juhász, T., \& Horváth-Csikós, G. (2016). Y and Z Generations at Workplaces. Journal of Competitiveness, 6(3), 90-106. https://doi.org/10.7441/joc.2016.03.06.

Gemnafle, M., Waimuri, S. P., Batlolona, J. R. (2018). Organizational Climate of the School and Teacher Performance Improvement in the $21^{\text {st }}$ Century. International Journal of Science and Research 
(IJSR), 7, (2), 119-126.

Hersey, H., \& Blanchard, K. H. (1977). Management of organizational behavior: Utilizing human resources, 3th ed., Englewood Cliffs, NJ: Prentice Hall.

Karwati, E., \& Priansa, D. J. (2014). Manajemen Kelas. Bandung: Penerbit Alfabeta.

Khan, M. A., \& Law, L. S. (2015). An integrative approach to curriculum development in higher education in the USA: A theoretical framework. International Education Studies, 8(3), 66-76. https://doi.org/10.5539/ies.v8n3p66.

Khoshhal, K. I., \& Guraya, S. Y. (2016). Leaders produce leaders and managers produce followers: A systematic review of the desired competencies and standard settings for physicians' leadership. Saudi Medical Journal, 37(10), 1061-1067. https://doi.org/10.15537/smj.2016.10.15620.

Lamb, A., Martin-Misener, R., Bryant-Lukosius, D., \& Latimer, M. (2018). Describing the leadership capabilities of advanced practice nurses using a qualitative descriptive study. Nursing Open, 5(3), 400-413. https://doi.org/10.1002/nop2.150.

Lazonder, A. W., \& Harmsen, R. (2016). Meta-Analysis of Inquiry-Based Learning: Effects of Guidance. Review of Educational Research, 86(3), 681-718. https://doi.org/10.3102/0034654315627366.

Leonard, L. D. \& Utz, R. T. (1974). Building skills for competency based teaching. New York : Harper \& Row.

Litsareva, E. (2017). Success Factors of Asia-Pacific Fast-Developing Regions' Technological Innovation Development and Economic Growth. International Journal of Innovation Studies, 1(1), 72-88. https://doi.org/10.3724/SP.J.1440.101006.

Lipham, J.M., Rankin, R.E., \& Hoeh, J.A. Jr. (1985). The Pincipalship: Concepts, Competencies, and Cases. New York: Longman, Inc.

Luyten, H., \& Bazo, M. (2019). Transformational leadership, professional learning communities, teacher learning and learner centred teaching practices; Evidence on their interrelations in Mozambican primary education. Studies in Educational Evaluation, 60(November 2018), 14-31. https://doi.org/10.1016/j.stueduc.2018.11.002.

Marshall, C. (2017). Montessori education: a review of the evidence base. Npj Science of Learning, 2(1), 1-9. https://doi.org/10.1038/s41539-017-0012-7.

Martin, S. N. (2019). Science education in Indonesia: past, present, and future. Asia-Pacific Science Education, 5(4), 1-29.

McGregor, D. (1960), The Human Side of Enterprise, McGraw-Hill, New York, NY.

Megginson, L. C., Mosley, D. C., \& Pietri, P. H., (1983). Management: Concepts and application. New York: Harper and Row.

Mulyasa, E. (2007). Kurikulum Tingkat Satuan Pendidian: Suatu Pendahuluan Praktis. Bandung: PT Remaja Rosdakarya.

O'Leary, S. (2017). Graduates' experiences of, and attitudes towards, the inclusion of employabilityrelated support in undergraduate degree programmes; trends and variations by subject discipline and gender. Journal of Education and Work, 30(1), 84-105. https://doi.org/10.1080/13639080.2015.1122181

Richter, T., \& McPherson, M. (2012). Open educational resources: Education for the world? Distance Education, 33(2), 201-219. https://doi.org/10.1080/01587919.2012.692068.

Sergiovani, T.J. 1987. The Principalship: A Reflective Practice Perspectives. Boston: Allyn and Bacon, Inc.

Slamet, P. H. (2000). Manajemen Berbasis Sekolah. Jakarta: Dirjen Dikdasmen Depdiknas.

Smith, W. C., \& Benavot, A. (2019). Improving accountability in education: the importance of structured democratic voice. Asia Pacific Education Review, 20(2), 193-205. https://doi.org/10.1007/s12564019-09599-9

Stukalina, Y. (2010). Kokybės valdymo procedūros taikymas mokymui: I \{ogonek\} mokini \{ogonek\} orientuotos mokymo aplinkos valdymas. Technological and Economic Development of Economy, 16(1), 75-93. https://doi.org/10.3846/tede.2010.05.

UNESCO. (2012). Working paper series on mobile learning: turning on mobile learning in Latin America. Paris. UNESCO.

Usman, H. (2011). Manajemen: Teori, Praktek dan Research Pendidikan.Edisi ke 3. Jakarta: Bumi Aksara.

Wagner, John A., and John R. Hollenbeck. Organizational Behaviour: Securing Competitive Advantage. New York: Routledge, 2010, pp. 49-50. 